\title{
THE CONCEPTUALIZATION OF TIME AND SPACE IN THE MEMORY THEATRE OF GIULIO CAMILLO (I480?-I 544$)^{\mathrm{I}}$
}

\author{
Anne Aurasmaa
}

In the 17th century collections became ideally more or less the presence of all things material. Interest leaned towards the mundane and the common and collecting became a gathering of everything. This trend can already be seen to some extent in the natural history collections of the 16th century. As a counterbalance to this I would like to put forward in this paper the idea that the 16th century collections pictured the whole universe as a construction combining time and space. It was not the intention just to fill rooms with collected material examples but to present the phenomena by showing their boundaries and to help the spectator to understand the building blocks of the universal hierarchy. The theatrum mundi - or curiosity cabinet, as 16th century collections are more commonly referred to - was conceived as a presence of all that existed in one place. Instead of collecting everything, and claiming that such a collection would represent the world as it is (or as it can be perceived by the senses), rhetorical themes, abstract ideas and universal structures were visualized by means of displaying the strangest objects from the most faraway places. The function of such displays was to bridge the gap between the universal $\operatorname{logos}^{2}$ and the human logos. Logos meaning reason and structure is the opposite of myth and personal sensory experience and as such includes thinking, speech, relations and regularities. The concept can be used both in reference to universal order and to the faculties of the human mind.

The basis for the inter-relating of groupings and links between objects and sentient beings, as well as locations and times was provided by natural philosophy, classical rhetoric, and the
Neo-Platonist ideas that became increasingly prevalent from the 15th century onwards.

As part of this development in 16th century Italy, the study of history came to be de- 
52 fined as the act of observing the development of the world from a particular vantage point. As Donald R. Kelley has argued, the first "renaissance definition" of history was provided by George of Trebizon in 1434 in his treatise on rhetoric. He understood history as an accurate description of past events expressing topical and chronological order. ${ }^{3}$ Such a definition explains history as a kind of narrative which is linked with past "reality" (i.e. multitude), but has a structure and a direction, existing in time and space. Considering history as a narrative means that it is not believed to be the (objective) truth but rather a slice of reality as seen from a certain vantage-point. Later Daniël Heinsius (1580-1655) defined the idea of the narrator of history in his $D e$ praestantia ac dignitate historiae oratio (1614) as follows:

He would be free from the limits of time and space... and would gather into one focus the immeasurable great vastness of generations... He would view in a moment an indefinite multitude of matters and affairs. ${ }^{4}$

Heinsius' discourse, in implying an externalization of the observer, expresses the modern concept of the subject. History was thus made an object. In order to gain a position "outside" the material world, the renaissance observer went deep into his own mind and analysed his knowledge of the world following the Platonian process of knowing. ${ }^{5}$ In the words of Giulio Camillo:

If we join ourselves to this mens we may understand, through the ray from God $^{6}$ which is in it, all things, present, past, and future, all things... which are in heaven and earth. ${ }^{7}$

To his contemporaries Camillo was famous for building a "memory theatre". The principles of organization of this theatre were applied to further late 16th century collections. The model was structured according to the principles of classical rhetoric. It was an aid to understanding the universe and an occult space. ${ }^{8}$ Camillo explains the use of the theatre, comparing it to different perspectives. The material world for him was like being in a forest; a person was only able to see separate elements (in a collection this would be the objects and materials). Reaching for the level of planets ${ }^{9}$ was like stopping to look at the view while climbing a hill. From such a vantage point a person would be able to see more, and catch glimpses of the truth (in a collection this would mean seeing relations and meanings). Reaching the top of the hill enabled the viewer to see the whole picture (in a collection this would be abstract categories, reasons), and that was where the observer was placed in Camillo's theatre. Camillo concludes:

In order to understand things of the lower world it is necessary to ascend to superior things, from whence, looking down from on high, we may have more certain knowledge of the inferior things. ${ }^{10}$

He gives reasons for the importance of this lofty view:

This high and incomparable placing not only performs the office of conserving to us the things, words and the arts which we confide to it, so that we may find them at once whenever we need them, but also gives us true wisdom from whose founts we come to knowledge of things from their causes and not from their effects. ${ }^{11}$

The positioning of the observer in Camillo's memory theatre prefigures Heinsius' definition of history as a (personal) observation. While standing outside both happenings in the material world and time, the observer in his mind is present everywhere - an idea which echoes a conceptualization of God. ${ }^{12}$ Agrippa of Net- 
telesheim (Heinrich Cornelius, 1486-1535), who collected a great amount of occult knowledge of the early 16th century, explains "according to Platonists" that God is the centre of the world but he denies that man can occupy this position although he places high value on the spiritual part of a human being:

The soul is a substantial number, uniform, conversive unto itself, and rational, very far exelling all bodies and material things...for it is not a quantitative number, but removed from all corporeal laws, whence it is not divided nor multiplied by parts. Therefore the soul of man is a certain divine substance, flowing from a divine fountain, carrying along with itself number: not a divine one by the which the Creator hath disposed all things, but a rational number by the which, seeing it hath a proportion to all things, it can understand all things. ${ }^{13}$

In spite of Agrippa's negative attitude towards unio mystica ${ }^{14}$, I suggest that Camillo's theatre features one of the first instances of a modern subject as the definer of his own world-view. In the 16th century such a position could have been reached only in rather private circles. Secret collections or studiolos offered an excellent place for study and meditation where one could define one's concept of world hidden from the eyes of the Church and Camillo's structured rhetoric concept was easy enough for a learned person to grasp, but offered endless levels and meanings to meditate on as part of one's spiritual growth. Not quite a co-incidence, I presume.

The interest in Neo-Platonism - and in many cases hardly separable from it, in occult philosophy - spread rapidly from court to court and among the learned. It promised new means whereby to express and use power and to better one's social status. In order to use occultism or magic to one's advantage, it was necessary to understand its operating principles. Marsilio Ficino (1433-1499), who alongside Pico della Mirandola (1463-1494) was an important Neo-Platonist working close to the Medici court, noted that "the ancients"15 claimed that a model of the universe was useful if one wanted to capture the heavenly powers. ${ }^{16}$ Ficino was probably thinking of jewellery or something of similar size, but the idea also found expression on an architectural scale. Quite a number of princely and scholarly collections, aimed at picturing the world and using it to their advantage, emerged from the Renaissance onwards. Among them were the two famous and still existing studiolos of the Medicis' but also more abstract occult constructions such as the memory theatre of Giulio Camillo. ${ }^{17}$

\section{Camillo's construction}

They say that this man (Camillo) has constructed a certain Amphitheatre, a work of wonderful skill, into which whoever is admitted as spectator will be able to discourse (on) any subject no less fluently than Cicero." Later he visited the theatre and describes it: "The work is of wood, marked with many images, and full of little boxes; there are various orders and grades in it... When I asked him concerning the meaning of the work, its plan and results - speaking religiously and as though stupified by the miraculousness of the thing he threw before me some papers, and recited them so that he expressed the numbers, clauses, and all the articles of the Italian style... He calls this theatre of his by many names, saying now that it is a built or constructed mind and soul, and now that it is a windowed one. He pretends that all things that the human mind can conceive and which cannot (be) see(n) with the corporeal eye, after being collected together by diligent meditation may be expressed by certain corporeal signs in such a way that the beholder may at once perceive with 
Reconstruction by Frances A. Yates,

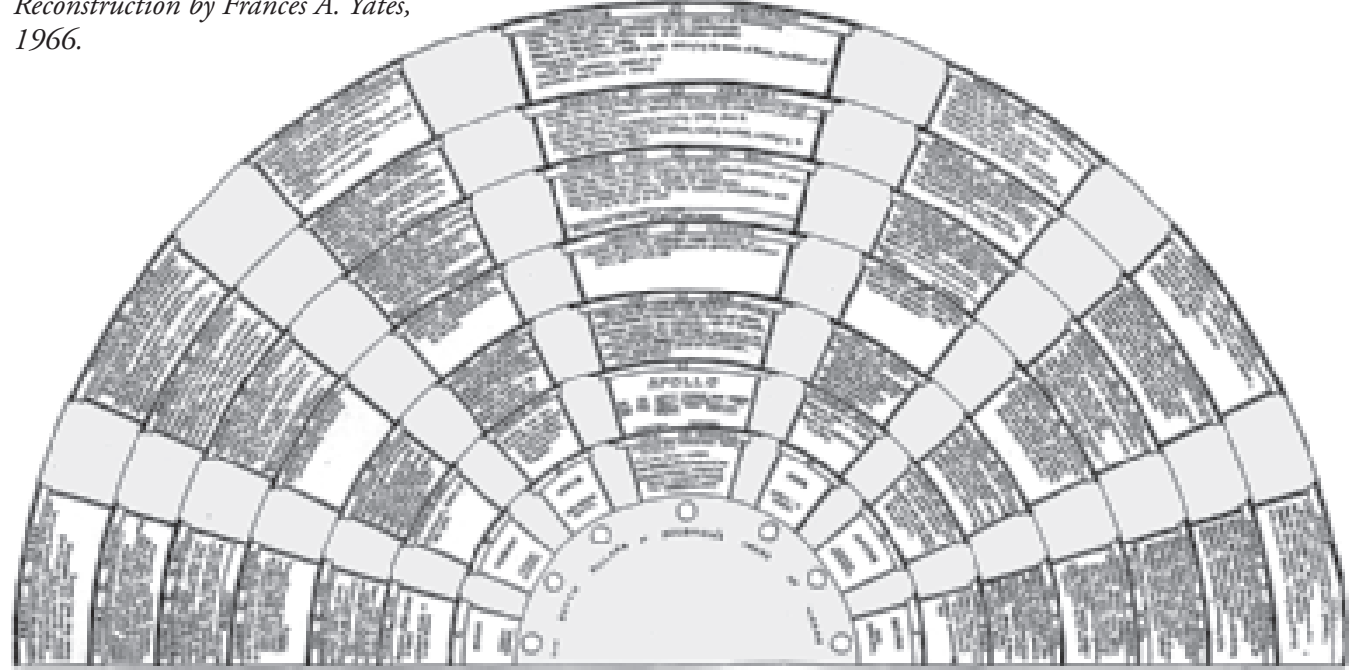

his eyes everything that is otherwise hidden in the depths of his human mind."

Viglius Zuihemus in a letter to Erasmus. ${ }^{18}$

According to Frances A. Yates, Camillo used a form of a Vitruvian theatre in an attempt to explain material and time-bound existence. ${ }^{19}$ The construction represented the universe, and in its final completed form was supposed to contain knowledge of all things. Along with Cabala, other occult sources and traditional authorities, Camillo refers to Plato's Timaus as a myth of creation. He also refers to Plato when explaining some of the numerical hierarchies in his theatre. ${ }^{20}$ The number harmony of Plato's universe ${ }^{21}$ and basic Cabalistic numerology ${ }^{2}$ are here combined in order to analyse the meaning of the theatre according to Agrippa and based on hints given by Camillo. ${ }^{23}$ The structure of the theatre is formed of two transverse, seven-level categories. The number of levels sustains the universalism of the theatre in several ways. According to the Jewish Cabala based on classical Neo-Platonism, the life of the universe had seven phases conducted by seven planets or Sefiroths, which were considered to be intermediary beings. This concept was known to Christians at the time of the Renaissance. ${ }^{24}$ According to Agrippa:

These [planets or angels] are those seven spirits which always stand before the face of God... These govern all things by a certain vicissitude of hours, days, and years, as the astrologers teach concerning the planets which they are set over; which therefore Mercurius Trismegistus calls the seven governors of the world, who by the heavens, as by instruments, distribute the influences of all the stars and signs upon these inferiors. ${ }^{25}$

A numerical construction of the universe also had a known Christian tradition. According to Augustine (354-430), who was well versed in Neo-Platonism (and thus, had a world view which closely resembled that of the Cabalists), 
the process of history, as an unfolding (evolutio) of God's will, comprised seven stages. ${ }^{26}$ According to Agrippa all physical existence, including that of the human body, consisted of four material elements known since antiquity (fire, air, water and earth). These existed in different things in varying proportions to each other. The soul, however, consisted of a threefold power: procreation, sensibility, and rationality, none of which was material. ${ }^{27}$ The last three represented in a person the spiritual levels of the universe. Thus the theatre was an image of a microcosm, and especially of man as a microcosm, since seven was the number asigned to humanity. As Ficino noted, only man resembled God in being a union of the spiritual and the physical. For this reason, by means of meditation, in gaining an insight into himself, man could gain insight into the whole universe. ${ }^{28}$

In his theatre, Camillo named the series from left to right after the planets (including the moon). Planets had several meanings in the Renaissance, especially in occult philosophy. They were allegories: the gods of antiquity or different aspects of the human character. They were also presentations of different concepts or transmutations between God and humankind, as well as a visible expression of the flow of time. Richard Behrenheimer reads them as archetypes in his analysis of Camillo's theatre. ${ }^{29}$ The series in Camillo's theatre was ordered from those closest to those furthest away, and according to the astrological conception of the alteration of the dominant planets, as explained by Ficino or the Cabala. ${ }^{30}$ The planets exerted their influence in varying combinations at different levels in the universe, at different times (hours, months, years, and so on) and during different phases of human life and the life of the universe. Thus the series formed several cycles, structurally identical but differing in size, to be interpreted as varying levels of the universe: closer or further away from the material or the spiritual respectively.

The relation of the grades of the theatre to the hierarchy of the universe was presented as an evolutionary progress, in which the myths of ancient Greece were connected to the Biblical story of creation, as Frances A. Yates wrote in the $1960 \mathrm{s.}^{31}$ This evolutionary story, as told by the grades, can be interpreted as an Augustinian, and thus a traditional Christian, concept of the material world as decaying and changing in time. If we join to this interpretation the view of the Cabala - according to which the individual played a key role in making the world a better place ${ }^{32}-$ and consider each part of the series as a universal period dominated by one planet, then by thinking our way through the theatre, we can travel in time from creation to the end of time which is simultaneously the original state of the universe, when everything was in a state of perfection. This is a journey made by a person towards an inner knowledge through the acquisition of supposedly Platonist knowledge emanating from the primeval memory.

The first in the series of Camillo's theatre, read from left to right, is Diana, the moon, and the series ends with Saturn. In terms of the allegorical meanings of the planets, the series portrays the universe on the one hand as the cycle of nature, and on the other as the linear experience of life. It presents a curve moving from the foolishness of youth (Diana) to the prime of manhood (Apollo in the centre) and then to the wisdom of old age ( $\mathrm{Sa}$ turn). ${ }^{33}$ Even if the material theatre ends at this point, it cannot be considered the end of everything. For example, Agrippa joins the liv- 


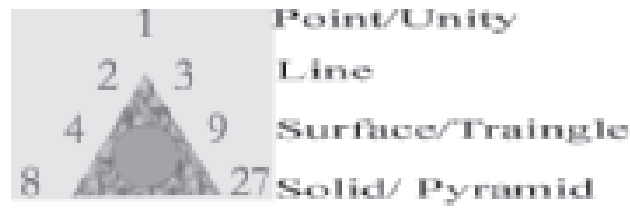

Mathematical structuring of the universe according to Plato's Timaus.

ing world and human death into a never-ending existence:

The world is a rational creature, immortal; man in like manner is rational but mortal, that is, dissolvable: for (as Hermes saith) seeing the world itself is immortal, it is impossible that any part of it can perish. Therefore to die, is to name in vain, and even as vacuum is nowhere, so also death; therefore we say a man dieth, when his soul and body are separated, not that anything of them perisheth or is turned into nothing. ${ }^{34}$

From death in Saturn, the seemingly linear movement of time in Camillo's theatre is towards the better and the origin (or the original paradise) because, in addition to being associated with death, Saturn is also linked to birth. In alchemy, for example, Saturn is symbolised by the colour black or darkness and is the first level to be attained in the search for the philosopher's stone. ${ }^{35}$ In other words, Saturn signifies the first step towards purification into a nobler and brighter state of mind. The classical circular movement of time, like the cycle of nature, is expressed in the theatre: death is followed by birth and vice versa. It also makes known that what was in the beginning will come again. The idea of metempsychosis, which can be read from the Timaus of Plato $^{36}$, and seems to be expressed in the theatre, means that the space behind the stage, although invisible, is part of the universe. In its

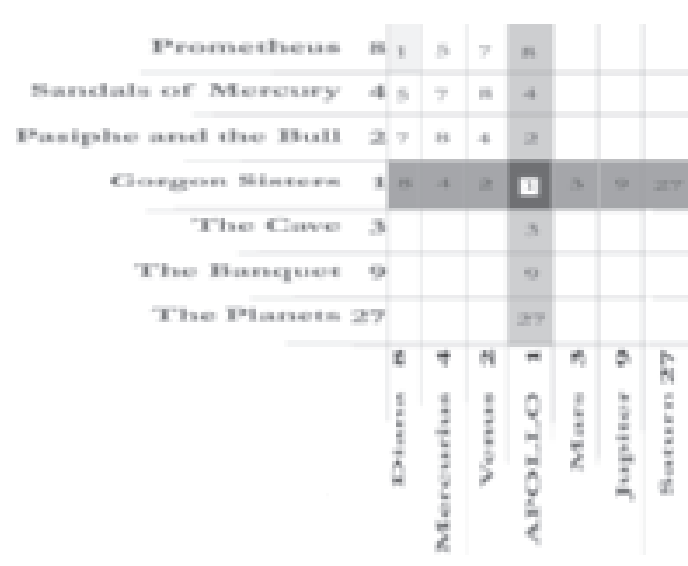

invisibility darkness represents everything opposite to life. Yet it is essential to rebirth and evolution.

Camillo brings us all the circles of time; yet his theatre appears not as a simple cycle of eternal life and inevitable return to the original state. Reading the construction suggests a change. For example, the recurring lifespan of the soul and the Cabalist universal phases - as a duality of the perfect and the imperfect, or of rest and motion - is transferred in Camillo's theatre into a visible trinity where Apollo signifying the perfection of manhood - a perfection expressed in the balance of the physical and the spiritual - is placed in the centre, with material feminine youth, and spiritual masculine old age at either end. In numerology this can mean that the left side presents even numbers, and the right the odd spiritual numbers of Plato's Kosmos ${ }^{37}$, as described in the Timaus. According to Ficino, Saturnic wisdom is a state one cannot reach without Apollonic virility. Only a balance between physical and mental exercise can ensure spiritual development, which stresses the role of a person in joining the material and the spiritual spheres of the 


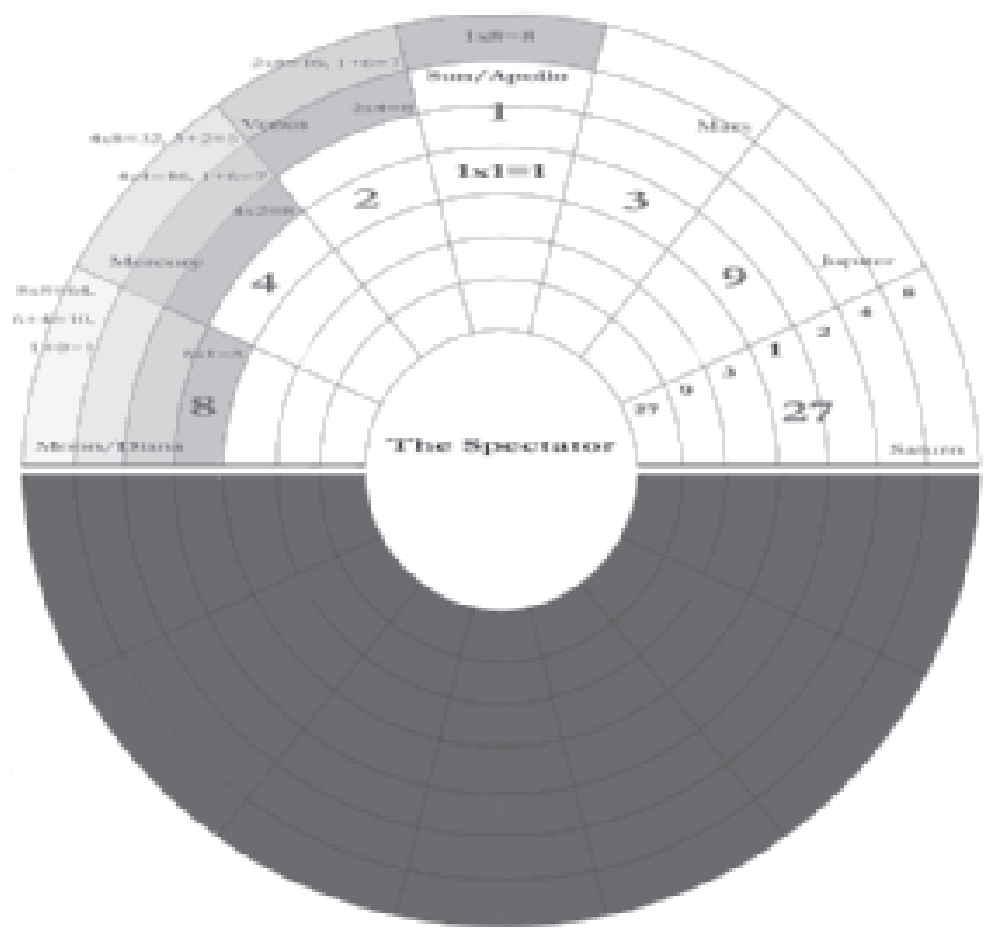

universe. ${ }^{38}$ These beliefs, as contemplated by the Neo-Platonists of the Renaissance, mean returning to the same states of personal and universal development over and over again. But, unlike the view of the natural philosophers, Camillo's theatre can be read in such a way as to suggest that every return is a move into a new grade. Every new period of universal time is different from that which precedes it. I suggest that this was possible only because of belief in the real effects brought about by the spectator in and on the space.

The myths already offer an endless number of meanings to contemplate in Camillo's theatre. It can be read in several ways, and a series of interpretations can be made through associatively combining and connecting its parts.
Yates has pointed out the stability of the theatre. For her this means that the occultism was not fully developed and all the possibilities of creating meanings through connections were not realized. ${ }^{39}$ Considering the structure in the light of Plato's universe, leads to a slightly different view of the theatre. In Timaus Plato presents the mathematical (or musical) foundation for the universe and universal harmony, where the dimensions increase by multiplication. He follows the Pythagorean concept of the universe as a series of changes, where the starting point is the unity which is all-inclusive, and what follows is a consequence of that which comes before. ${ }^{40}$ If we assign these numerical values, which in Timaus were said to be the basic structure of the universe, to each 
Anne Aurasmaa

58

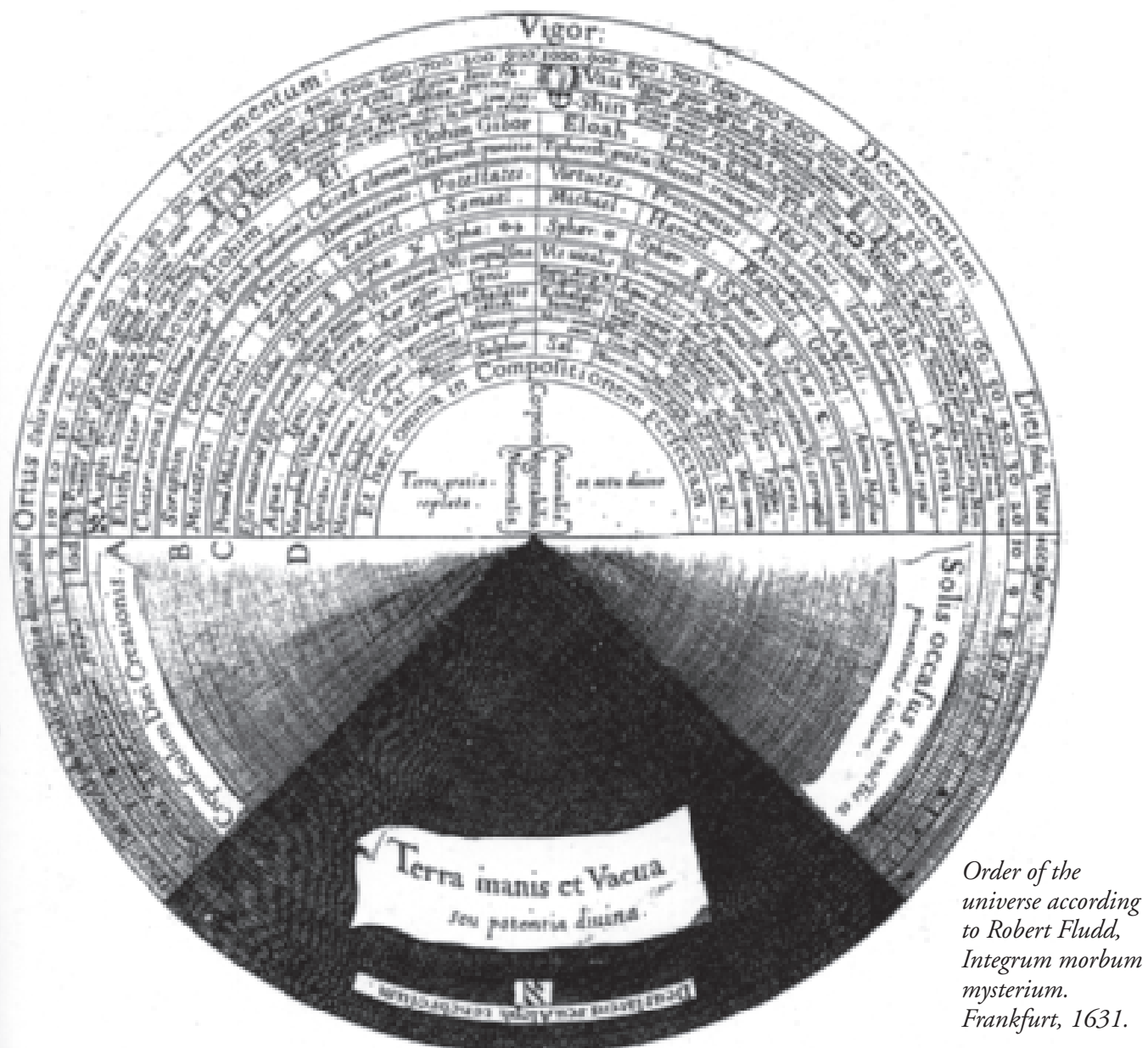

category created by cross-indexing the grades and series in Camillo's theatre, according to numerology, we find a new layer of meanings and also a possible method for reading the theatre as a microcosmic picture of the universe in all its aspects, not just as a picture of the material world. The first structural meaning however is on very basic material level. Through studying Agrippa's concept of the universe - as explained by Donald Tyson - based on a combination of Plato's Timeus and natural philosophy, it is possible to see the elements in Camillo's theatre by dividing it into four groups separated by the series of Apollo and the grade of the Gorgon Sisters. ${ }^{41}$

As Yates has already shown the evolution of the material universe in Camillo's theatre, in allegories of the grades, I will make a closer study of a tiny sample of the theatre, examining the existence of the concept of time as such 
and in particular of progressive time: The numerological sequence from Diana-Prometheus to Apollo-Gorgon Sisters proceeds from one to one (which, as we know from Agrippa, was a divine number), but the ones are not equal; the first is a step lower in Cabalist mathematical hierarchy than the other. The combination Apollo and Gorgon Sisters is created by calculating 1 $\mathrm{x} 1$, which comes to 1 , but Diana's Prometheus is actually $10\left(8 \times 8=64^{\prime} 6+4=10^{\prime} 1+0=1\right){ }^{42}$ The first numbers $1,5,7$ (when we proceed forward from the furthest left ${ }^{43}$ ) all have some numerological meanings connected to human existence. According to Agrippa, one represents Adam as the father of mankind, five signifies parenthood and the sexes (2, female; 3 , male), seven is man with full powers of mind and body. ${ }^{44}$ The number sequence $8,4,2,1$ follows the structure of Timaus' universe towards the simpler forms of material existence. Man returned to the possibility of unity in Apollo's Gorgon Sisters, which is in the middle of the theatre. Thus, the numerological diagonal from one level and series to another enabled the progress of the earthly pilgrimage from its material beginning to its Apollonic, masculine blossoming.

Plato's number sequence raises the Gorgon Sisters to a kind of unity signifying man on earth as an image of God. As Agrippa explained earlier, in this position man is the highest of material beings, the brightest image of God, but still unable to see Him and understand the universal construction "from above". The Gorgon Sisters, three sisters who form one because they only have one shared eye, in Camillo's theatre represent the three human souls or the three levels of consciousness and action. They refer to man's divinity, attained through the Holy Trinity, (three spiritual qualities joined in a person). In the Apollo series the Gorgon Sisters are at their peak: first among the best of material existence, the king, for example, as body and mind, a whole person. The movement from the grade of the Gorgon Sisters towards the centre of everything (the stage of the theatre) can thus be interpreted as a transition from the most perfect image of God to the real God who, like man alone of all creation, comprised variety in all its forms, but still remained outside it. ${ }^{45}$ This movement and compression of time and space into the mind of one being joins the personal and the universal mens into one.

If the above suggestion expressing the idea of man's divinity is accepted as a characteristic of Camillo's theatre, the copying Camillo's constructing principles would have transferred the idea to the theatrum mundi- the collections of the philosophically oriented princes. In order to see it in this way more discussion is needed on the position of the spectator. Placing on the stage is of the utmost importance. ${ }^{46}$ If the theatre is seen as a representation of the whole of existence, the person at the centre is the centre of everything. In the occult universe the Pythagorean original and invisible fire (the beginning and reason for everything, a metaphor for God) was in the centre; its visible sign was the sun. The original fire would be placed on the stage in the universe of Camillo's theatre because the sun was already placed among the planets. According to the Greek Neo-Platonist, Proclus (410458) (much read during the Renaissance) immaterial light existed as an absolute place located in the centre of everything and the cosmos was located in this light. The revolving movement of the cosmos and the motion of its parts were visible against the light. ${ }^{47}$ In Camillo's theatre the spectator is in real space outside the pictured material universe, and at 
60 the same time at the centre of it, as if he were the original fire itself, if we accept the presence of cyclic time in the theatre. Under these premises it can be said that the spectator in Camillo's theatre is in God's place and time where everything exists simultaneously. Time and space appear collapsed in the theatre but are in fact present in the observer's mind and ability to understand their existence, and see their meaning in the forming of connections and in the significance of things that, in the theatre, represent the material and time-bound existence of the universe. The observer can see the whole picture. He can understand the past and predict the future from the things he knows if he has a noble mind or is enough of a genius (high-spirited ${ }^{48}$ ).

\section{IN TIME}

In the 16th century, time was established as the fourth mathematical dimension. This means that it was possible to express time and space in similar, numerical, terms. The search for and discovery of the mathematical conception of time offered a sort of "empirical" foundation for astrology and universal magic. It is part of this understanding of time that material objects move in space along predictable tracks. The time of the universe could not be influenced; it passed by at its own steady pace and was thus similar to other non-changeable aspects of existence, for example, space. Unlike universal time, the experience of the soul's time, like place in the universe, was under control of each individual. With the help of a universally organized theatrum mundi collection or a memory theatre of Camillo's type (which can be seen as the same thing), it was possible to make a personal study of smaller or larger (or more material or spiritual) parts of the universe. These parts of the universe could one control if one used the acquired knowledge in the correct way. Knowledge about the things in the collection passed through the observer's mind as abstractions of the 'real world' and he could enter into a kind of dialogue between the collection as an abstraction of the universe and as collection from the real material world. All parts affected each other and understanding the "larger picture" was impossible without comparison between the lived and the familiar, and the collected world with its strange things from the far ends of the tree of life.

In order to work, the magical concept of reality requires the linear and the cyclic, or the pendulum of time, to be moulded into a spiral of time, or to be more precise, all of these have to exist simultaneously. The predictability, permitted because of the repetition of the cycle, and the linearity of the mathematical concept of time together with the pursuit of perfection trusting in the ultimate perfection of the past, enabled change to be anticipated and the distant past and present to be used to understand the future. On the level of the individual material time passes and understanding increases while one moves physically or mentally among the things and ideas presented in the theatre. Following this process makes it possible to approach universal logos in the mind, and gain increasingly greater control over matters by simply being able to see, handle and understand more, and thus become more like God in his unity and knowledge of everything. In the pursuit of the "truth" the theatre, as a material memory, was meant to help build the universe into the mind of the viewer. With the help of the theatre the observer sought in his inner universe a route to his own divinity and, thus, to understan- 


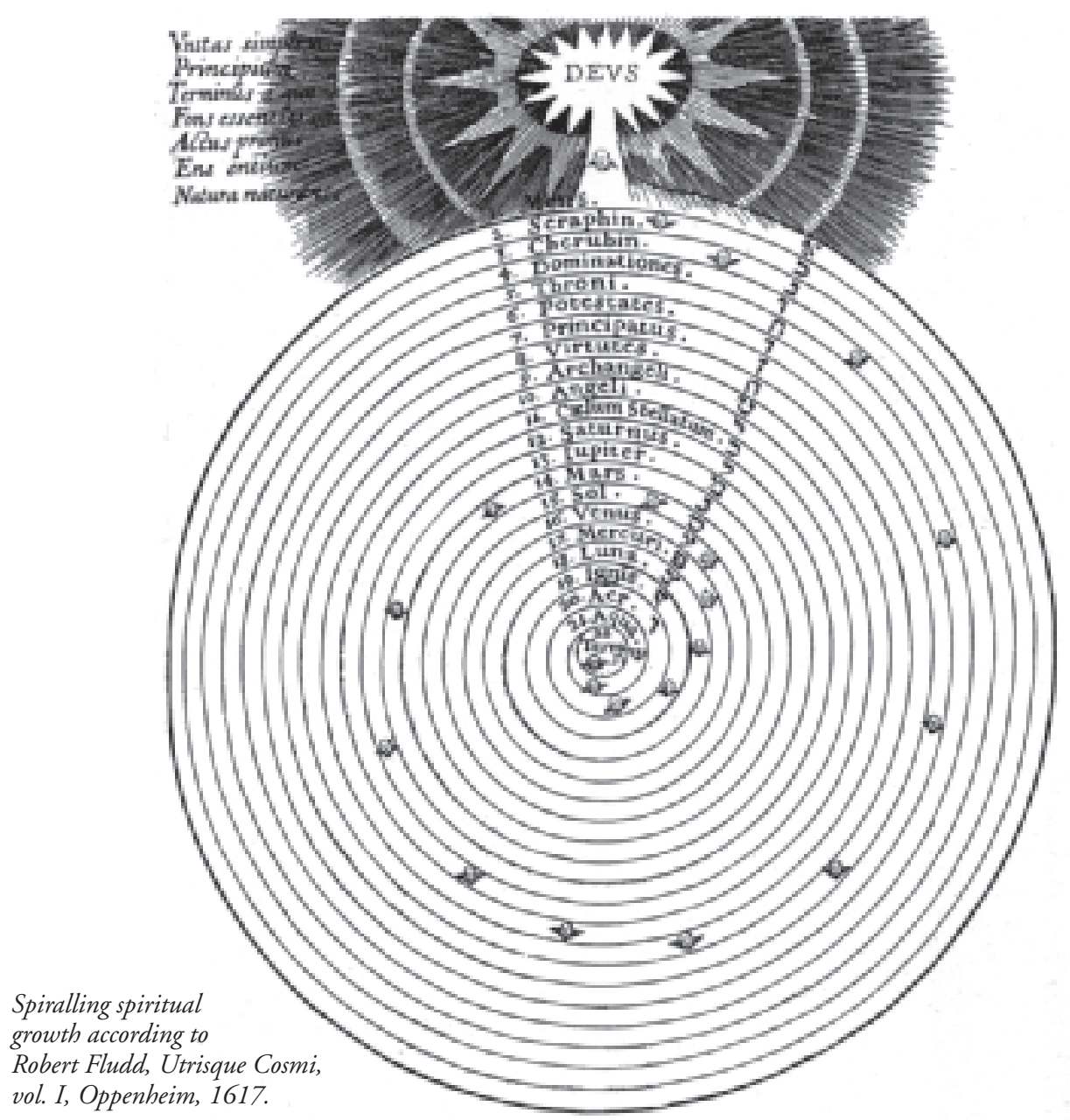

ding and controlling reality. This task was made possible by understanding both space and time material like any other objects of study of the large family of things of existence ruled by the mathematical, harmonic structure of the universe, the first extension which was created before the ideas. Everything could be compressed by calculations and the reduction of dimensions to one point and moment in a mind that was great enough. Such a mind was the first modern subject, the prince in the middle of his private collection.

As has been said earlier, the construction of Camillo's theatre affected the princely studiolos of the 16th century. Of special interest here are the Medicis, who started to collect at the same time as interest in Neo-Platonism blossomed in 15 th century Florence. They also in- 


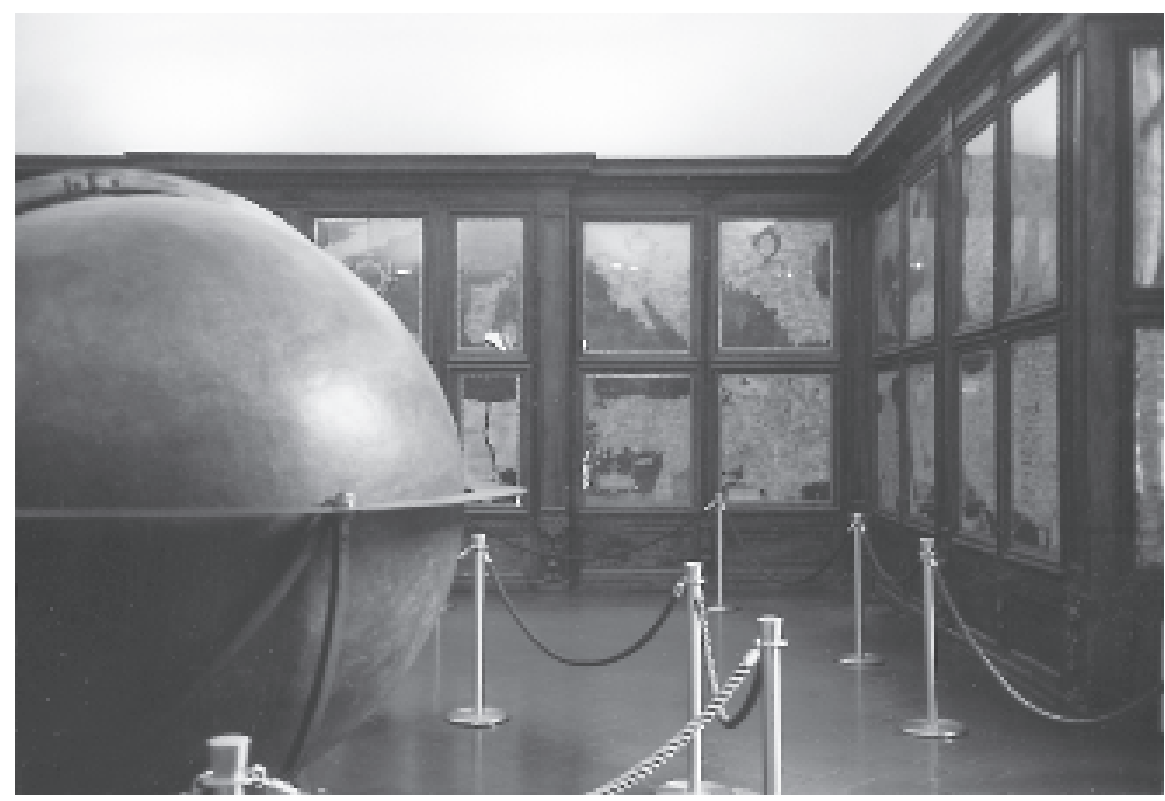

Studiolo of Cosimo de Medici.

fluenced collecting and collection arrangements around Europe in the late 16th century. Several members of the Medici family had secret studiolos. Three of the studiolos can still be seen in Palazzo Vecchio. The oldest is just a tiny room, but the two collection chambers from the 16th century still have their cupboards and paintings. Cosimo de Medici's (1519-1574) collection was organized geographically. Maps of the known world cover the doors of the closets. In the centre of the room is a globe and an armillary sphere, as if the universe had been turned outside in. Francesco de Medici's (1541-1587) private collection was mounted around 1572, when he inherited the position of head of the family. The room is covered with paintings representing allegories of material and spiritual elements and aspects of the universe as well as living people of his, time arranged from material and earthly to spiritual and heavenly. This "stanzino del prinzipe" is famous for its alchemical symbolism. In both of the studiolos, the owner-spectator occupied the central space in the room and was able to study closely the hidden items if he wanted and needed to. This basic and material aspect of the collection can be considered the owner's first step on a progressive journey towards a nobler and a wiser person and a better, more unified universe. This was the aim of a self-aware person according to the Renaissance occult, and the Christian Cabala we have studied above. ${ }^{49}$ The maps and paintings helped the observer to connect things together and form abstract ideas once the unique examples in cupboards were sufficiently 
familiar. The owner of the collection used the maps and paintings on the doors of the cupboards and on the ceiling as tools to create an artificial and architectural rhetorical memory. ${ }^{50}$ He structured and articulated his understanding of the meanings and connections of the objects and progressed from observing individual instances to comprehending the larger wholes. Even later in his progress, once he climbed the hill, to use Camillo's metaphor, he was in control of his whole universe (on top of the hill). The observer was not a mere observer anymore, and was not only able to comprehend the structures and meanings but to arrange and rearrange things. This means that he saw the universe from the outside as one huge, but mathematically ("scientifically") arrangeable, understandable and controllable body, and was able to form any wanted and needed narrative out of it. The piece of material universe that was his collection, when abstracted in his mind, condensed all knowledge into one, to be used in the material universe around the person, and reused again in reorganizing the collection and his personal world-view.

Camillo's theatre, as analyzed here from the point of view of occultism, implies that the universal theatrum mundi was not a chaotic and personal accumulation of objects and knowledge based only on random associations and sophisticated metaphors or analogies, but a flexible combination of philosophy and metaphysical beliefs. The philosophical "boundary hunting" in collections was born out of an abstract, universalizing and holistic world view. From the base, which was founded on an exact picture and experience of reality, one could, and was supposed to, advance to personal interpretations and abstract theories. The spiritual traveller was supposed to distance

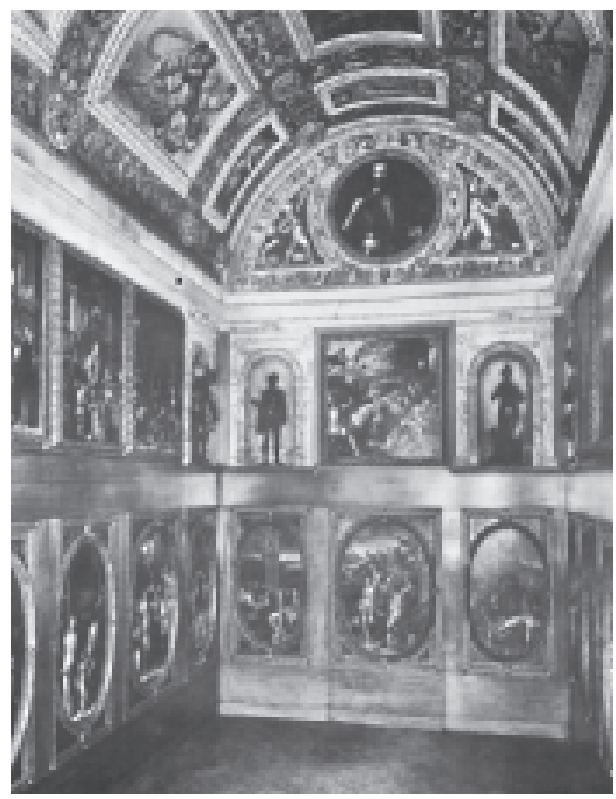

Stanzino del principe Lorenzo de Medici.

himself step by step from earthly things such as feelings and sense-experriences and move towards knowledge and understanding as higher forms of being. When this was done with the help of an occult collection, the aim was not to indulge in private or purely meditative thought, but to be in constant dialogue with the material world and the whole universe.

The layered meanings made the occult version of the rhetorical art of memory and the mundane theatrum mundi formed the fertile foundations for the concept of the modern museum with its aim to teach, aid study, and structure the world. The combination of contradictory ideas and metaphors that could be interpreted in different ways and could be used in varying combinations (including the occult ones) represented the organisation of the cha- 
64 os of the visible and temporally changing diversity. The collection was mounted in order to seek the unity that was believed to exist or the main working principle of the living universe. The personal character of the readings drawn from the material examples in the theatre allows the interpretation to be made that, until the final stage of unity was achieved, all readings were personal and narrowly missing the point. With the progression from generation to generation (or life to life) better explanations, and visions of the universe were expected to emerge resulting from the structural permanence of the theatre and the accumulation of information, knowledge and wisdom. Trust in the ability to access the structural level meant that, despite the visible chaos, it was worth studying the diversity in order to advance understanding of the meaning of life. The perfect universe was thought to be attainable, if not on a material, at least on a theoretical level. Collecting examples of the differences among things was considered to function as an aid to the realization of all concepts and ideas. At the same time the change and progress in the universe meant that a complete material collection was not feasible. All material, including knowledge in time-bound being was essentially in constant motion.

\section{Notes}

1. The following text is based on the author's dissertation Salomonin talo presented in 2002. Cf. the review by A.Waenerberg in Nordisk Museologi 2002/2, p. $119 \mathrm{ff}$.

2. Varto $1995,88$.

3. Kelley 1988, 749.

4. Heinsius 1940, 10, translation by G.W. Robinson.

5. While, in Aristotle, the human mind is seen as a tabula rasa, which learns by sensory experience,
Platonicism suggests a process of knowing by turning the soul towards ideas rather than sensory matters. Richard Popkin explains the concept in the Renaissance connection: the mind withdraws into itself from the bodily concerns. It comes to know its own nature, the intelligible world of Platonic ideas and to know God. Popkin 1988, 673-674.

6. "God" must be understood in philosophical connection as an abstract concept including materia and life in all its forms, ability to procreate and change and as all reasons (physical, chemical etc.) to natural or spiritual phenomenon. Gershol Sholem separates the theological more or less personal creator "God" from the more abstract "God" of Cabala who "stands... above being and nonbeing and in whom the two coincide". The same division should be done when studying the Renaissance occult thinking. Cf. Sholem 1987, 442.

7. Camillo 1990, 47-48, translation by Yates. Yates noted the divine origin of human mens in Camillo: "It is because he believes in the divinity of man that the divine Camillo makes his stupendous claim of being able to remember the universe by looking down upon it from above, from first causes, as though he were God. In this atmosphere the relationship between man, the microcosm, and the world, the macrocosm, takes on a new significance. The microcosm can fully understand and fully remember the macrocosm, can hold it within his divine mens or memory." Yates 1966, 151-152. Cf. Camillo's contemporary Agrippa (of Nettelsheim) 1998, 585.

8. See Yates 1966, 135-162; Hooper-Greenhill 1992, 97-101; Bolzoni 1994, 129-168.

9 The picture Camillo is sketching shows Earth at the centre of the universe. The layers of planets and heavens cover it.

10. Camillo 1990, 63. translation by Yates.

11. Camillo 1990, 63. 
12. See note 6. Discourse on the concept and essence of Christian God has as long tradition as the Christian church. Most definitions admit the impossibility of defining such a concept, but several features of the "first cause" and "creator" have been written down. Agrippa draws a parallel but does not see a balanced relationship between the "conceptual God" and the "conceptual man", the concepts of philosophical discussion... Cf. Agrippa 1998, 585.

13. Agrippa 1998, 585. Agrippa also writes: "The masters of the Hebrews think that the names of angels were imposed upon them by Adam... the Lord brought all things which he made unto Adam, that he should name them, and as he called anything, so the name it was." Agrippa 1998, 532. Agrippa opposed black magic, his arts were supposed to be white and thus aiming for good.

14. Merging of man and God in meditation or some "more mystical" way.

15. Ficino refers to writings that were believed to be very old, especially of Egyptian, or even of divine origin. See also next note.

16. Ficino 1996, 151-153, 156, 158. Agrippa refers to the influence and use of heavenly powers in several instances. Agrippa 1998, 587. Yates discusses Ficino's magic in connection with Camillo's theatre. Studying the theatre foremost as a rhetoric construction and not so much as a material tool of power and universal understanding, she thinks that "the images of Camillo's theatre seem to be supposed to have in them something of this [talismanic] power enabling the 'spectator' to read off at one glance, through 'inspecting the images', the whole contents of the universe." Yates 1966, 157-159. Based on Thomas Aquinas, Agrippa explains the power of things and images. Agrippa 1998, 373.

17. Yates gives a lively picture of the nature of Camillo’s fame: "In 1578 J.M. Toscanus published at Paris his Peplus Italia, a series of Latin poems on famous Italians, amongst which is one on Camillo to whose marvellous Theatre the seven wonders of the world must do homage. In a note to the poem Camillo is described as most learned in the mystical traditions of the Hebrews who are called Cabala, and profoundly versed in the philosophies of the Egyptians, the Pythagoreans and the Platonists." Yates 1966, 140.

18. Viglius Zuihemus wrote to Erasmus 1532 regarding Camillo's theatre. Erasmus Epistolae X, 2930; translated and cited fully in Yates 1966, 136137.

19. Yates 1966, 140-141, discussion on the nature of Vitruvian theatre as an astrological construction based on geometry, 172-173; cf. Camillo 1990, 64-65.

20. Camillo 1990, 11-13, 60-61, 67, 70-72, 8182. Plato was known among Western Christianity only after the appearance of translations made by Ficino in the late 15 th century. Yates notes the connections between Sefiroths and the Platonic ideas in Camillo, and that these are combined with the classical art of memory. Yates 1966, 142; Camillo 1990, 62-63. On principles of classical art of memory, see Ad Herennium II xvi 28-xxiv 40. Agrippa gives questionable credit to Plato for the art of mathematical magic. Agrippa 1998, 692. Cf. Yates 1966, 162.

21. For a deep analysis of Plato's mathematical and musical structure of the universe, see Cornford 1935, 43-72. Cf. Dudley 1987, 20-21.

22. Meanings and connections found by means of numerical values given to words and things were the basis of all magic. These were studied in the Renaissance as being originally Cabbalist art. Agrippa makes clear the numerical ontology of the universe and celestial influences: "It is a general opinion of the Pythagoreans, that as mathematical things are more formal than natural, so also they are more efficacious: as they have less dependence in their being, so also on their 
operation. But amongst all mathematical things, numbers, as they have more form in them, so also are more efficacious, to which not only heathen philosophers, but also Hebrew, and Christian divines do attribute virtue, and efficacy, as well to effect what is good, as what is bad." Agrippa also advises to study Jewish mysticism. Agrippa 1998, 234, 533.

23. Agrippa writes: "Severinus Boethius saith, that all things which were first made by the nature of things in its first age, seem to be formed by the proportion of numbers, for this was principal pattern in the mind of the Creator. Hence is borrowed the number of the elements, hence is the courses of times, hence the motion of the stars, and the revolution of the heaven, and the state of all things subsist by the uniting together of numbers." Agrippa also refers to the ancient authorities: "The Pythagoreans say (Aristotle, and Ptolemy are of opinion) that the very elements of letters have some certain divine numbers, by which collected from proper names of things, we may draw conjectures concerning occult things to come. Whence they call this kind of divination arithmancy, because, viz. it is done by numbers."Agrippa 1998, 237, 312, 333, 336.

24. Agrippa 1998, 330; Scholem 1987, 446; see also The Book of Concealed Mystery, 2000, a late 13th century commentary on the Torah which tells the Cabalist version of the Biblical story of the Genesis.

25. Notice how Agrippa "hides" God from human gaze but still keeps him as part of the unified construction. Besides Christian considerations this idea can be traced to a Cabalist idea of division of the original unity in creation into two opposites which are expressed by the sexes. Agrippa 1998, 532-533.

26. Kelley 1988, 751.

27. Agrippa 1998, 268.

28. Ficino 1994, 86. Agrippa makes the microcosmic nature of man a simple matter: "God... created man after his image; for as the world is the image of God, so man is the image of the world".

Agrippa 1998, 579. Cabala sees man as a tree of life with a trunk, branches and leaves... The metaphor of tree brings light to occult relations, which could look unrelated and far from each other at first sight. When expressed in a human form the river of life is flowing along a man's backbone from the Paradise down to the mundane existence. The head represents the high capacities and the procreation is the lowest of human creative powers. In the visible universe this constant contact was expressed by the believed effects of the planets.

29. Behrenheimer 1956, 230.

30. Ficino 1994, 79-80, 159: Camillo 1990, 59-124.

31. Yates 1966, 145 (143-146). The levels were identical except for the Apollo, where the first two steps were reversed.

32. Baldesar Castiglione (1478-1529) and Anne Conway (1631-1690) write about human ability to "repair" the universe. One single act of importance is the joining of the sexes into an androgynous unity as is said to have existed before this universe according to the Cabalist tradition. Cf. Castiglione 1967, 218, 220; Conway 1996, 47; The Book of Concealed Mystery 2000, 16-30. Cf. Lohr 1988, 573. The idea of a single person being able by the practice of arts and meditation to repair the divided universe is a key issue in the formation of the modern concept of time as progressive and not just evolutionary. This also separates the modern personality from the medieval one.

33. I have used here the most common meanings given to the planets. They agree with Yates' reconstruction of the theatre.

34. Agrippa 1998, 579.

35. "What really is the Philosopher's Stone? It is nothing else but a compound of the white eagle 
and the red lion as produced by the artists." White eagle and red lion can be understood as chemical substances, of course, but the spiritual nature of the seek is clearly expressed in the rules for the seeker: "He who seeks the alchemical art for money and wealth but not to know better his creator and nature does not belong among the philosophers but among the idiots." Praxis Spagyria Philosophia 1998, 35, 89.

36. Plato Timaus 41E-42D. The concept of metempsychosis can also be based on observations of nature. I believe that the Agrippa's above mentioned living universe depended partly on this concept.

37. Beautiful order and harmony in all things.

38. Ficino 1994, 93.

39. Yates 1966, 196.

40. Plato Timaus 31A-36B. Empedocles (c.490430) suggested successive worlds, which is basically similar to the Cabalist history of the universe and can be considered in relation to Camillo's theatre. The problem is the formlessness of the continuity of time, which is undoubtedly missing from Camillo's structure. Cf. Sorabji 1988, 185; see also note 35 .

41. Tyson, 1998, 719-727.

42. Agrippa says: "The simple numbers signify divine things: numbers of ten; celestial: numbers of hundred; terrestrial: numbers of a thousand; those things that shall be in a future age." Agrippa 1998, 239. Cf. notes 21 and 28.

43. It must be remembered that a Cabalist reading can and must always be done in both directions.

44. Agrippa 1998, 241-242, 262, 268-273.

45. The discussion of the essence of God during the Middle Ages made several suggestions about God's possible interference or non-interference on Earth.

46. As far as I can tell, the placing of the spectator follows Pico's idea and can be considered to have an occult meaning. I believe that the concept of magus (the man of high spirit, wisdom and knowledge of occult arts) is here in the correct
Sisters), in contrast, can be read to follow Ficino's idea of man's universal position. Ficino put a man at the centre of the universe as the microcosm which repeated the order of the macrocosm. According to Pico, man's worth and distinctness was based on the fact that man was the maker of his character and thus his fate. In contrast to Ficino, Pico asserted that the position of man in the universal hierarchy was not permanent. Man could be almost anything he wanted and could become almost everything he wished. Pico proposed the absolute value and centrality of man, his cosmic responsibility, his freedom and dignity. Vasoli 1988, 68-69.

47. Siorvarnes 1996, 133-134, 247-252; Sorabji 1988, 109-111, 117. From reading Proclus it was possible to combine nicely the material and spiritual existence into one living universe.

48. Ficino talks about an inner daimon in the spirit of Iamblichus (c. 245-325). The spirit inside a person varies according to his state of progress. For Ficino a genius is a person who is never satisfied and always aims for something better. Ficino 1994, 172; Ficino 1985, 109-113; Iamblichus 1988 27-28, 36; Lohr 1988, 574-575.

49. As should be clear, for example, from the Augustinian periodic system of universal history, the change is not a new idea par excellence, but progress and the human capability to affect circumstances are.

50. On the use of artificial memory in the Middle Ages and in the Renaissance, see Carruthers 1992; Yates 1966.

\section{BIBLIOGRAPHY}

Ad Herennium (Ad C. Herennium libri IV De Ratione dicendi). (1954). Edited and translated by Harry Caplan. Loeb Classical Library. Harvard Univer- 
sity Press, Cambridge.

Agrippa of Nettelsheim, Henry Cornelius. 1998.

Three Books of Occult Philosophy. The Foundation Book of Western Occultism. Completely Annotated, with Modern Commentary. First published 1533. Translated by James Freake 1651. Edited and annotated by Donald Tyson. Llewellyn's Sourcebook Series, Llewellyn Publications, St. Paul.

Aurasmaa, Anne. 2002. Salomonin talo. Museon idea renessanssiajattelun valossa. Privately printed, Helsinki.

Behrenheimer, Richard. 1956. "Theatrum Mundi" in The Art Bulletin vol. XXXVIII/4, 225-247.

Bolzoni, Lina. 1994. "Das Sammeln und die Ars Memoriae" in Andreas Grote (hrsg.) Macrocosmos in Microcosmo. Die Welt in der Stube. Zur Geschichte des Sammelns 1450 bis 1800. Berliner Schriften zur Museumkunde 10. Institut für Museumskunde, Staatliche Museen zu Berlin Preussischer Kulturbesitz. Leske + Budrich, Opladen, 129-168.

The Book of Concealed Mystery. 2000. Translated by S.L. MacGregor Mathers 1877. This edition first published 1926. Ways of Mysticism. Continuum, London.

Boyer, Carl B. 1989. A History of Mathematics. First published 1968. Revised by Uta C. Merzbach. John Wiley \& Sons, New York.

Camillo [Delminio], Giulio. 1990. L'Idea del teatro e altri scritti di retorica. Alethes, Collezione di retorica 1. Esizione RES, Torino.

Carruthers, Mary J. 1992. The Book of Memory. A Study of Memory in Medieval Culture. First published 1990. Cambridge University Press, Cambridge.

Castiglione, Baldesar. 1967. The Courtier. Originally Il libro del cortegiano (1528). Translated and with an introduction by George Bull. Penguin Books, London.

Conway, Anne. 1996. The Principles of the Most
Ancient and Modern Philosophy. Translated and edited by Allison P. Coudert \& Taylor Corse. Cambridge Texts in the History of Philosophy. Originally published 1690. Cambridge University Press.

Cornford, Francis M. 1935. Plato's Cosmology. The Timaus of Plato. Translated, with a running commentary. Hackett Publishing Company, Indianapolis.

Dudley, Underwood. 1997. Numerology or, what Pythagoras wrought. Mathematical Association of America, Washington DC.

Ficino, Marsilio. 1994. The Book of Life. Translated by Charles Boer. First published 1980. Originally publised 1480. Spring Publications, Woodstock.

Ficino, Marsilio. 1985. Commentary on Plato's Symbosium of Love. Translation by Sears Jayne. Spring Publications, Dallas.

Heinsius, Daniël. 1940. The Value of History translated with notes and appendices by George N. Robinson. Originally published 1614 as De praestantia ac dignitate historiae oratio. Privately printed, Cambridge, Mass.

Hooper-Greenhill, Eilean. 1992. Museums and the Shaping of Knowledge. Routledge, London.

Iamblichus. 1988. The Exhortation to Philosophy. Including the letters of Iamblichus and Proclus' commentary on the Chaldean Oracles. Edited by Stephen Neuville. Translated by Thomas Moore Johnson; with a foreword by Joscelyn Godwin. Phanes Press, Grand Rapids, MI.

Kelley, Donald. R. 1988. "The theory of history" in Charles B. Schmitt, Quentin Skinner \& Eckhard Kessler (eds.) The Cambridge History of Renaissance Philosophy. Cambridge University Press, Cambridge, 746-762.

Lohr, Charles H. 1988. "Metaphysics" in Charles B. Schmitt, Quentin Skinner \& Eckhard Kessler (eds.) The Cambridge History of Renaissance Philosophy. Cambridge University Press, Cambridge, 537-638. 
Plato. (1929). Timæus in Plato in Twelve Volumes, IX. Timaeus, Critias, Cleitophon, Menexenus, Episteles with an English translation by R.G. Bury. Loeb Classical Library. Harvard University Press, Cambridge University Press, Cambridge.

Plato. Republic. (1994) Translated with an Introduction and Notes by Robin Waterfield. Oxford University Press, Oxford \& New York.

Popkin, Richard, H. 1988. "Theories of knowledge" in Charles B. Schmitt, Quentin Skinner \& Eckhard Kessler (eds.) The Cambridge History of Renaissance Philosophy. Cambridge University Press, Cambridge, 668-684.

Praxis Spagyrica Philosophica or Plain and Honest Directions on How to make the Stone by an anonymous author, 1998. Translated into English from the Original German first published in Leipzig 1711 with a commentary by Frater Albertus. Samuel Weiser, York Beach, ME.

Scholem, Gershom. 1987. Origins of the Kabbalah. Originally Ursprung und Anfänge der Kabbala, 1962. The Jewish Publication Society, Princeton University Press, Princeton.

Siorvanes, Lucas. 1996. Proclus. Neo-Platonic Philosophy and Science. Edinburgh University Press, Edinburgh.
Sorabji, Richard. 1988. Matter, Space \& Motion: Theories in Antiquity and Their Sequel. Duckworth, London.

Tyson. Donald. 1998. "The Elements" in Agrippa of Nettelsheim, Henry Cornelius. 1998. Three Books of Occult Philosophy. The Foundation Book of Western Occultism. Completely Annotated, with Modern Commentary. Edited and anno- tated by Donald Tyson. Llewellyn's Sourcebook Series, Llewellyn Publications, St. Paul. 719-727.

Varto, Juha. 1995. Kannettava filosofinen sanakirja. Filosofisia tutkimuksia, Vol XXVII. I painos 1992. Tampereen yliopisto, Tampere.

Vasoli, Cesare. 1988. "The Renaissance concept of philosophy" in Charles B. Schmitt, Quentin Skinner \& Eckhard Kessler (eds.) The Cambridge History of Renaissance Philosophy. Cambridge University Press, Cambridge, 57-74.

Yates, Frances A. 1966. The Art of Memory. Pimlico, London.

Anne Aurasmaa, $\mathrm{PhD}$

Taidehistoria, PL 3

FIN-00014 Helsingin yliopisto

e-mail:aurasmaa@mappi.helinki.fi 
Artiklar om MUSEIHISTORIA I TIDIGARE NUMMER AV NORDISK Museologi

\section{FURTHER READING ON} SIMILAR SUBJECTS AVAILABLE IN Nordisk Museologi

$1993 / 1$

Mogens Bencard, Museerne og Verdensordenen. Kunstkammerets opståen og grundidé.

$1993 / 2$

Annesofie Becker, The Genealogy of the Museum. Arthur MacGregor, Antiquarian attitudes. Changing responses to the past in the museum environment. $1994 / 1$

Mogens Bencard, Kunstkammers and Museums. Beat Wyss, The Tübingen Conspiracy.

Arne Losman, Skoklosters slott - en minnesteater. $1994 / 2$

Peter Wagner, Från kunstkammer til moderne museum.

Hemming Andersen, Fysik og museum. Hauchs fysiske Cabinet.

$$
1996 / 1
$$

Marie Nisser, Industriminnen under hundra år. $1996 / 2$

Ritva Wäre, The National Museum of Finland 19161996 - from Preservation to Presentation.

Daniel P. Hopkins, Peter Thonning and the Natural Historical Collection of Denmark's Prince Christian (VIII) 1806-1809.

$$
1997 / 1
$$

Anne Aurasmaa, Adolf Etholén and Ernest Erickson. The Founders of the North American Indian Collections in the National Museum of Finland.

$$
\text { 1998/1 }
$$

Janne Vilkuna, C.R. Ehrström och Brahestad - ett stycke finsk museihistoria.
$1999 / 1$

Brita Brenna, Et sant og levende bild av verden - verdensutstillinger og museihistorie.

Lennart Palmqvist, De första renässansmuseerna i Rom och Florens.

Janne Vilkuna, The Finnish Museums Association 75 years working for museums.

$1999 / 2$

Claes Hallgren, Hjalmar Stolpe: en folkbildares utställningssyn.

Christer Nordlund, Organising Geology for Display. The Museum of the Swedish Geological Survey 1871-1915.

$$
\text { 2001/1-2 }
$$

John Aage Gjestrum, "Museumsmænd og deres skidne tøi”.

John Aage Gjestrum, Fra folkemuseum til økomuseum.

John Aage Gjestrum, Utstilling af levende mennesker Esben Kjeldbak, Post-modernism and the Three Generations of Museums.

Jørgen Hein, Repræsentation eller belæring?

Zygintas Bucys, Sources of the National museum of Lithuania.

$$
2002 / 2
$$

Vésteinn Ólason, Håndskriftenes hjemkomst.

Anna Torbjörg Torgrimsdóttir, Återlämning av isländska föremål 1930.

Inge Adriansen, Tilbageføring mellem Danmark og Tyskland.

Arne Thorsteinsson, Tilbage til Færøerne. 